\title{
Rевевсни автіск: Knowledge and attitude of farmers towards soil health cards in Krishna district
}

Article Chronicle : Received :

15.02.2020;

Revised:

04.10.2020;

Accepted :

23.. 10.2020

\section{KeY WoRds :}

Direct sown paddy, Seed drill, Adoption of the technologys
SUMMARY : Soil testing is well recognized as a sound scientific tool to assess inherent power of soil to supply plant nutrients. Soil health card (soil test result) can be used to optimize the use of fertilizer in the integrated nutrient management (INM) system. It is essential to create maximum awareness among farmers about judicious use of chemical fertilizers and use of soil health cards. Ten farmers randomly selected from ten different villages that have availed soil testing technique with the total of 100 farmers. The data collect through personal interview method with the pre-tested schedule designed for the purpose. Majority of respondents had poor knowledge regarding soil testing practices but respondents with 45.00 mean per cent score had maximum knowledge regarding benefits of soil testing. While, maximum knowledge gap was observed in proper technique of sampling for horticultural crops. It was also observed that majority of farmers were in positive attitude (72\%) with "Soil testing is necessary for better crop production". Majority of the farmers (76\%) did not agree with the statement that "Soil testing is wastage of time and money". Half of the $(50 \%)$ respondents expressed that expenditure of crop production decreases after soil testing. Sixty one (61) per cent adopters said that, "Soil testing is very long process". Therefore, as per problem faced and suggested by the farmers more scientific and educational trainings and facilities are required to disseminate the technology at large.

How to cite this article : Srilatha, P. and Srilatha Vani, Ch. (2020). Knowledge and attitude of farmers towards soil health cards in Krishna district. Agric. Update, 15(4): 397-400; DOI : 10.15740/HAS/AU/15.4/397-400. Copyright@2020: Hind Agri-Horticultural Society.
Author for correspondence :

\section{P. Srilatha}

Krishi Vigyan Kendra, Ghantasala, Krishna

(A.P.) India

Email : srilathajeyabal@ gmail.com

See end of the article for authors' affiliations 